\title{
Determinants of educational performance in Uruguay, 2003-2006
}

\author{
Cecilia Oreiro and Juan Pablo Valenzuela
}

ABSTRACT

Students' performance at the lower secondary level in Uruguay is examined on the basis of the mathematics scores compiled by the Programme for International Student Assessment (pisa) for 2003 and 2006. An effort is made to analyse the differences in score distributions, to identify the variables influencing students' performance and to trace the trends over that period and weigh their significance. In order to do so, a production function for educational achievement is defined and a number of different decomposition methodologies are applied. The findings indicate that the small increase in scores between 2003 and 2006 is the net result of differing changes, most of which are primarily the result of an across-the-board increase in the school system's efficiency, especially in the case of public schools. However, this improvement is partially offset by reduced resource endowments and, in particular, unfavourable socioeconomic and cultural conditions in many of the students' households. Most of the changes that are analysed in this study are found to be of a redistributive nature.

KEYWORDS

JEL CLASSIFICATION

AUTHORS
Education, quality of education, measurement, evaluation, secondary education, public schools, private schools, Uruguay

D39, I24, O38

Cecilia Oreiro, researcher with the Institute of Economics of the University of the Republic, Uruguay. coreiro@iecon.ccee.edu.uy

Juan Pablo Valenzuela, researcher with the Centre for Advanced Research in Education (cIAE) and the Department of Economics of the University of Chile. jp.valenzuelab@gmail.com 


\section{I}

\section{Introduction}

This study's objective is to analyse the status of basic secondary education in Uruguay and to identify the reasons for the differences observed between students' scores on the mathematics portion of the test administered by the Programme for International Student Assessment (PISA) in 2003 and 2006.

Since the year 2000, the PISA test has been administered to students aged 15 (regardless of what grade they are in) in the member countries of the Organisation for Economic Cooperation and Development (OECD) and in a number of partner countries. The results can be used to examine how students' performance varies depending on the grade that they are in, which provides an indicator of how much they learn as they move up from one grade to the next.

The study will look specifically at the mathematics test results because this was the main focus of the 2003 assessment, which is the only one that can be used as a comparison with the 2006 results. The objectives of this analysis are to establish whether significant differences exist between the PISA scores for 2003 and 2006, identify the factors (characteristics of the students, features of the schools or institutional variables) that account for differences between the scores for those two years, and determine whether such differences are attributable to

This study is based on a Master's thesis written for the School of Economics and Business of the University of Chile, January 2011. The authors are grateful for the valuable assistance received from Alejandro Sevilla.

\section{II}

\section{Background}

\section{The social and economic context}

Historically, Uruguay has had one of the lowest levels of inequality and one of the lowest poverty rates in Latin America. Until the mid-1990s, its per capita income was rising, income distribution was fairly stable, and variations in the magnitude of those factors, in how "efficiently" they have been used, or both.

In line with Valenzuela and others (2009a), a number of different methods for decomposing score differentials are used, including those of Oaxaca (1973), Blinder (1973) and Juhn, Murphy and Pierce (1993). An analysis based on microsimulations of the type outlined by Bourguignon, Fournier and Gurgand (1998) is also undertaken.

The potential contribution of this study to the economic and social development of the Latin American countries lies in the possibility it offers to draw conclusions about the quality of the education system and its heterogeneity which will be useful in identifying avenues for improvement. The PISA test can be used as a tool for comparing progress in Latin America with the advances being made in the developed world and with those taking place in other countries of a similar level of development. In addition, the use of decomposition techniques that are not widely applied in the field of education paves the way for a methodological approach that can be highly useful in gaining a better understanding of trends in educational achievement and that can be replicated in other school systems in the region, as well as being used for comparisons across countries.

This article is structured as follows. Background information that provides a frame of reference for the study is given in section II, while the methodology used for the analysis is described in section III. Section IV reports on the results, which are then compared in section V. Section VI concludes.

poverty was on the decline (Amarante and Perazzo, 2008). In the second half of that decade, income levels began to descend and income concentration increased slightly, while poverty levels began to rise. In 1999, the first signs of a recession began to appear, and by 2002 the country was in the midst of a deep economic crisis. 
All the economic variables worsened, there was a steep drop in GDP and per capita income, income distribution became more unequal, and poverty rates climbed sharply.

As the crisis was brewing, international emigration increased to a striking level. The country's negative migration balance is estimated to have amounted to 100,000 people in 2000-2004 and to 26,000 between 2005 and 2006 (Pellegrino and Koolhaas, 2008). A majority of the Uruguayans who emigrated were between 20 and 29 years of age. Most were males with an above-average level of education. In addition, a large proportion of the emigrant population was composed of entire family groups.

The level of economic activity in the country began to rebound in 2003 and gathered steam in 20042006, which proved to be a period of rapid economic growth. This recovery was not mirrored in the trend in household income until late 2005, however, and it was not until 2006 that significant reductions were seen in indigence levels, the poverty rate and poverty intensity (UNDP, 2008).

\section{Education in Uruguay}

The compulsory basic education cycle in Uruguay is nine years in length: six years of primary education and three of basic secondary education. Both academic secondary schools (liceos) and vocational schools use the same curriculum. Academic secondary schools are run by the Secondary Education Council (CES), while technical schools are administered by the Council for Technical and Vocational Education (CETP). The second cycle of secondary education is also three years in length and leads to a diploma known as a "diversified baccalaureate" if the student has attended an academic secondary school, and to a degree known as a "technical baccalaureate" if the student has attended a vocational school. CETP also offers basic training and basic vocational instruction, in addition to advanced occupational training.

The economic recovery that came in the wake of the 2002 crisis was coupled with a slight rise in the privateschool enrolment rate. This increased private schools' share of total enrolment at that level, but the traditional pattern, in which public schools have predominated, remained intact (Cardozo, 2008). This growth phase came to an end in 2004. Enrolment in secondary education fell in 2004 and 2005 and remained steady in 2006. The decline registered in 2004 reflected lower enrolment in public schools, whereas the number of students in vocational and private schools rose. In 2005, enrollment also fell in vocational schools but rose for the second year running in private schools. Nonetheless, the overall rate was lower once again. The decrease in the total enrollment rate in 2003-2005 is attributable to a reduction in the number of students completing their primary education and to international emigration (ANEP, 2007a).

A comparison of the number of persons who should have been attending school with the number of persons who actually did attend yields a more accurate measurement of the extent of educational coverage in each sector. The secondary-school attendance rate for 15 -year-olds in 2006 was $79.7 \%$, which is a gain of five percentage points over the attendance rate in 2003. This increase is a reflection of an upturn in rural coverage, which climbed from $51.8 \%$ to $69.2 \%$ during that time period, while urban coverage (towns with a population of over 5,000) held steady (ANEP, 2007b).

Uruguay participated in the 2003 and 2006 PISA exams. Its students obtained some of the highest scores in Latin America, but performed considerably less well than students in OECD countries. Uruguay's performance was also one of the most uneven of all the participating countries - far more unequal than the OECD countries as a group and even, in 2006, more so than the other countries of the region (ANEP, 2004 and 2007b).

Between 2003 and 2006, Uruguay's average score on the PISA mathematics test rose from 422.2 to 426.8 score points (an increase of just $1.1 \%$, which is not statistically significant). The question arises, however, as to whether this change in the average score from one period to the next might be the result of shifts in opposite directions in different social and institutional variables. The question as to whether given factors are generating movements in different directions and of different magnitudes will be explored by using methodologies that make it possible to decompose the effect of each relevant factor.

The PISA test results are also presented in an ordinal classification of academic performance. For the mathematics test, six proficiency levels are identified. Figure 1 shows the percentage of students at each of those levels in 2003 and 2006. As can be seen from the graph, $49 \%$ of Uruguayan students were below level 2 in 2003 (i.e. their level of proficiency is not sufficient to enable them to use mathematics in their daily lives). This means that they also run a high risk of being unable to participate fully in civic affairs or to gain entry to many of the occupations associated with an informationand knowledge-based society. Another $48.5 \%$ were at intermediate levels (2, 3 and 4 ), while only $2.6 \%$ were rated at the top two levels (5 and 6). These last two levels equate with highly developed mathematics skills relative 
FIGURE 1

\section{Percentage of students at each proficiency level, pisa mathematics test, 2003 and 2006}

2003

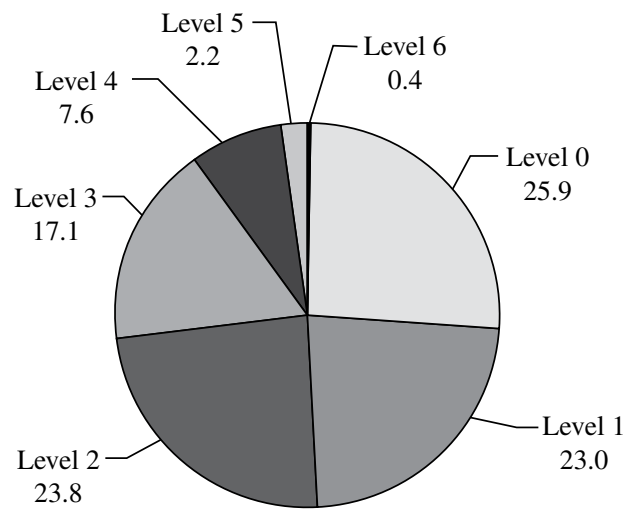

2006

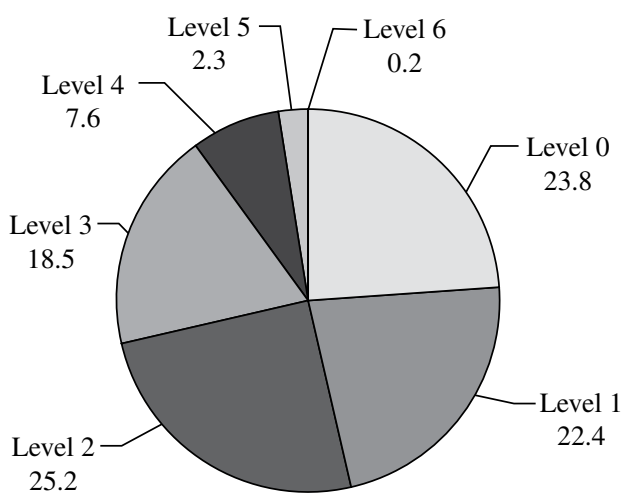

Source: Authors' calculations based on data from the Organisation for Economic Cooperation and Development (OECD), "PISA 2003" and "PISA 2006" [online] http://www.pisa.oecd.org/document/51/0,3746,en_32252351_32235731_39732595_1_1_1_1,00.html

to the students' age and identify the group of students for which the educational system has performed the best. A comparison of the students' performance on the 2006 and 2003 tests shows that the percentage of students at the lowest proficiency levels fell by $2.8 \%$, while the percentage at the intermediate levels rose by $2.8 \%$;

\section{III}

\section{Methodology}

\section{General methodology}

\section{(a) Production function}

The first step in determining the methodology to be used is to define a production function that relates each student's PISA score to a set of explanatory variables (socioeconomic variables relating to the student and his or her family, as well as school-related variables and institutional factors):

$$
Y_{i}^{t}=X_{i}^{t} \beta^{t}+\varepsilon_{i}^{t}
$$

where $Y_{i}^{t}$ denotes the score achieved by student $i$ in a given school at time $t ; X_{i}^{t}$ represents the observable the percentage of students at the top levels remained virtually the same. This appears to signal an upward progression, but such a gradual one that, if this trend were to remain constant, it would take half a century before no Uruguayan student was scoring at the lowest levels of proficiency in mathematics. characteristics of the student, the school and institutional factors; $\beta^{t}$ corresponds to the estimated coefficients for the various control variables; ${ }^{1}$ and $\varepsilon_{i}^{t}$ is the error term, which is assumed to have a standard distribution with zero mean and a variance of $\sigma_{\varepsilon}^{t}$ and to be independent of the exogenous variables of the model.

\footnotetext{
${ }^{1}$ Because of the way in which the PISA test results are expressed, the coefficients are estimated using five plausible values, which means that the regressions have to be estimated five different times, after which the mean for the estimates has to be calculated in order to arrive at the statistical value. The variance is adjusted for each estimate and for the whole distribution.
} 
The variables that were selected for use in the statistical analysis are shown in table A.1 of the annex; ${ }^{2}$ table A.2 lists the main descriptive statistics.

\section{Imputation methodology}

Given the large percentage of data that are missing for the PISA exam, ${ }^{3}$ a way has to be found for dealing with the affected observations. Ammermüller (2004) states that the usual approach is to eliminate an observation from the regression if the value for any of the explanatory variables is missing. This greatly reduces the number of observations that can be used to arrive at estimates, however. ${ }^{4}$ In addition, it generates a selection bias in the sample if the distribution of omitted values is not random.

In line with Valenzuela and others (2009a), the method used here consists of imputing the value of the median for a similar subgroup (i.e. a group having similar values for the different control variables), so that the observations for which data are imputed belong to fairly homogenous subgroups. The control groups used to define these subgroups are gradually reduced so as to eventually impute all the observations for which data are missing. ${ }^{5}$

When working with data that display a significant degree of variability, whether in the scores in each case or in the values that are imputed because data are missing, simply applying the mean values may result in the omission of the level of uncertainty of the measurement. This can distort the estimates of standard errors calculated for the parameters, which is particularly a problem in the case of effects that are near the significance limit. The calculation of standard errors thus includes the weightings for 80 balanced repeated replications (BRRs) in the database, with the Faye correction (0.5). These standard errors provide the degree of variation for any

\footnotetext{
2 The selection of variables was based on a number of prior national and international studies, including, in particular, those of Llambí and Perera (2008), Méndez and Zerpa (2009) and Hanushek and Woessmann (2010).

3 For both tests, the missing data primarily concern the variables corresponding to the schools, with the largest gaps being $4 \%$ of the data missing in 2003 for the variable "Percentage of certified teachers" and $3.8 \%$ of the data missing in 2006 for the variable "Shortages of qualified mathematics teachers".

${ }^{4}$ Specifically, if the estimates were performed without correcting for the missing data, 461 observations would have to be eliminated from the 2003 sample and 377 would have to be removed from the 2006 sample (i.e. nearly $8 \%$ in each case).

5 The effectiveness of this method, measured as the percentage of matches between the observed variable and the imputed variable for each iteration, works out to $60 \%$, which surpasses the scores for the methodologies applied by Ammermüller (2004) and by Fuchs and Woessmann (2004).
}

statistic with respect to the population parameter, and the replications take account of the survey's complex design (which was conducted in two stages using a stratified sample).

\section{Decomposition methodology}

The methodological approach used here consists of a number of different techniques for decomposing differences in scores: Oaxaca (1973), Blinder (1973), Juhn, Murphy and Pierce (1993) and Bourguignon, Fournier and Gurgand (1998).

The first two methodologies have been applied by Valenzuela and others (2009b) and by Bellei and others (2009) to identify the reasons for the differences in the scores of Chilean students on the 2006 PISA mathematics and reading tests as compared to the scores of students in Poland, Spain and Uruguay. Valenzuela and others (2009a) also used microsimulations to identify explanatory factors for the improvement in 15-year-old Chilean students' scores on the PISA reading test between 2001 and 2006, as well as factors that could help to account for the increased inequality of those scores. These were the main methodological references used in this study.

\section{(a) The Oaxaca (1973) and Blinder (1973) decompositions}

The decomposition method proposed by Oaxaca (1973) and Blinder (1973) provides a way to decompose differences in results for two groups of people or for two different years. This decomposition methodology involves three effects. One corresponds to the different results that individuals belonging to the same group may achieve as a consequence of their varying characteristics (the "characteristics effect"). Another corresponds to the differences in the level of efficiency with which the group's members make use of those characteristics (the "return effect"). And, finally, there is a combined "characteristics-return effect".

For the years being considered ( $t$ and $\left.t^{\prime}\right)$, given a variable for the mean mathematics scores $(Y)$ and a set of explanatory variables, the Oaxaca-Blinder approach makes it possible to estimate how much of the difference between mean scores is accounted for by differences in the explanatory variables for each year:

$$
R=E\left(Y_{t}\right)-E\left(Y_{t}^{\prime}\right)
$$

where $E(Y)$ represents the expected value for the PISA mathematics scores in a given year. 
Obtaining estimators by ordinary least squares (OLS) of $\beta_{t}^{\prime}$ and $\beta_{t}$ separately for the two samples $\left(\hat{\beta}_{t}^{\prime}\right.$ and $\left.\hat{\beta}_{t}\right)$ and using $\bar{X}_{t}^{\prime}$ and $\bar{X}_{t}$ as estimators for $E\left(X_{t}^{\prime}\right)$ and $E\left(X_{t}\right)$, the decomposition can be expressed as:

$$
\begin{array}{r}
\left.\hat{R}=\bar{Y}_{t}-\bar{Y}_{t}^{\prime}=\left(\bar{X}_{t}-\bar{X}_{t}\right)^{\prime}\right)^{\prime} \hat{\beta}_{t}+\bar{X}_{t}{ }^{\prime} \\
\left(\hat{\beta}_{t}-\hat{\beta}_{t^{\prime}}\right)+\left(\bar{X}_{t}-\bar{X}_{t^{\prime}}\right)^{\prime}\left(\hat{\beta}_{t}-\hat{\beta}_{t^{\prime}}\right)
\end{array}
$$

In this equation, $\bar{Y}$ reflects the mean score on the mathematics text for each of the years in which the PISA exam was administered. The first term in the equation corresponds to the effect of the means of the control variables, which are the explanatory variables that have been incorporated into the production function (see equation No. 1), i.e. the variables for students, for schools and for institutional factors. The second term of equation No. 3 corresponds to the effect of differences in the coefficients associated with these observed variables (in other words, the productivity or effectiveness of these factors). The third term reflects the interaction between these two effects (i.e. the characteristics-return effect).

(b) The Juhn, Murphy and Pierce (1993) decomposition Juhn, Murphy and Pierce (1993) applied the Oaxaca-Blinder (1973) methodology on a broader scale, developing a methodology for decomposing changes in the score distribution and for looking at their effects in the various parts of the distribution.

The first requirement of the proposed methodology is to obtain the residual $\varepsilon_{i t}$ as a function of two elements: the percentile in which individual $i$ is located at time $t$ in the residual distribution $\theta_{i t}$, and the residual distribution function for the results in $t, F_{t}(\cdot)$. Then, to define:

$$
\varepsilon_{i t}=F_{t}^{-1}\left[\frac{\theta_{i t}}{X_{i t}}\right]
$$

This makes it possible to estimate the score distribution for each year and to separate out the effects of changes in observable characteristics, returns and residuals; to this end, various estimations are performed for each year, and an initial estimation is performed for the regular form of results for each year:

$$
R_{i t}^{(1)}=\beta_{t} X_{i t}+F_{t}^{-1}\left[\frac{\theta_{i t}}{X_{i t}}\right]
$$

A second estimation is then carried out for the results of year $t$, while referring to the returns and residuals for year $t^{\prime}$ :

$$
R_{i t}^{(2)}=\beta_{t}^{\prime} X_{i t}+F_{t}{ }^{\prime}(-1)\left[\frac{\theta_{i t}}{X_{i t}}\right]
$$

Finally, the regular form for each year can be estimated, but this time with reference only to the residuals for the other year:

$$
R_{i t}^{(3)}=\beta_{t} X_{i t}+F_{t}{ }^{(-1)}\left[\frac{\theta_{i t}}{X_{i t}}\right]
$$

This method makes it possible to decompose changes in the inequality of the results into three components: the "characteristics effect": $R_{t}^{(2)}-R_{i t}^{\prime(1)}$, the "return effect": $R_{i t}^{,(2)}-R_{i t}^{,(1)}$ and the "characteristics-return effect": $\left(R_{i t}^{(1)}-R_{i t}^{(2)}\right)-\left(R_{i t}^{,(2)}-R_{i t}^{,(1)}\right)$. The remainder is a "residual effect" that measures variations in inequality that are not explained by any of the other three factors: $\left(R_{i t}^{,(3)}-R_{i t}^{(1)}\right)$.

\section{(c) Bourguignon, Fournier and Gurgand (1998) decomposition}

Other authors generalize the microsimulations method, using it to understand changes in the total distribution. This methodology was originally developed by Almeida dos Reis and Paes de Barros (1991) in order to analyse labour income inequality. Later, it was extended to the analysis of income inequality and poverty on the basis of total per capita household income. The first study to move in this direction was that of Bourguignon, Fournier and Gurgand (1998), who applied this methodology to decompose changes in household income inequality for Taiwan Province of China.

\section{Estimation of the production function and choice of school}

The decomposition begins with the estimation of the production function (see equation 1). This function is estimated for each year and for each type of school (public and private) by oLs. The choice between these two types of schools for each student is also modeled using a logit estimation.

A word of caution about the risk of selection bias is called for here. A positive correlation between 
the type of school and a student's level of educational achievement may be produced by a selection bias. This bias may be due to the fact that a family's choice of school is an endogenous decision taken as a function of its own characteristics. This possibility needs to be borne in mind when analysing the results. ${ }^{6}$

\section{Counterfactuals for changes in student characteristics}

With this methodology, calculating the characteristics effect entails finding the simulated result for individuals at time $t$ if, all else remaining constant, characteristic $k$ of vector $X_{k i}^{t}$ has the distribution of time $t^{\prime}$. In line with Valenzuela and others (2009a), different methodologies are used depending on the types of variables involved. In the case of dichotomous variables, we look at the unweighted percentage of cases in which the characteristic is displayed in period $t$ ', and that datum is simulated in $t$. However, possession of the characteristic for period $t$ ' has to be linked to each individual in $t$. In order to determine the probability of each individual displaying the observed characteristics, we estimate a probit regression in t', which gives us the probability in $t$ that the characteristic is exhibited, in accordance with the other conditions of $t$ '. Once these probabilities are placed in descending order, we then look for the cut-off point based on the observed percentage of individuals who have the characteristic in $t^{\prime}$. The categorical variables are simulated by means of a multilogit estimation in $t^{\prime}$ and, once again, a probability of possession of the characteristic is assigned to each individual in $t$, after which the cut-off point is located on the basis of the observed percentage of individuals that exhibit that characteristic in $t^{\prime}$.

In the case of the continuous variables, this approach involves looking at population groups constructed on the basis of the type of school and the size of the population centre. ${ }^{7}$ Using these groups, we look at the minimum number of observations that match from one period to the next in a single group and then use this set of observations to construct quantiles for which the mean per group and quantile can be calculated. Then, using this mean for each year for the variable that is to be simulated, we construct a factor - the relationship

\footnotetext{
${ }^{6}$ One possible way of dealing with the selection bias is to use the two-step Heckman adjustment. In order to use this method, however, the selection model would have to contain at least one exclusion variable, which was not possible in this study.

7 In some instances, adjustments have to be made in order to make the simulation more precise, in which case other variables can be used for the population groups as well, such as grade or grade repetition.
}

between the mean for year $t$ ' and the mean for year $t$ - that is a multiple of the simulated variable for each subgroup in the population and quantile.

\section{Counterfactuals for changes in returns}

The microsimulation of educational attainments while introducing changes in the vector of returns (vector of coefficients for the effectiveness of inputs) involves determining the counterfactual results that a student would attain at time $t$ if, ceteris paribus, the returns to those characteristics were to change (i.e. those corresponding to period $t^{\prime}$ ). To do so, we have to simulate the results obtained by students at time $t$ while incorporating the estimated parameters for those returns for period $t^{\prime}\left(\hat{\beta}^{t^{\prime}}\right)$ while maintaining the same observable and unobservable characteristics and the structure of the school selection procedure for time $t$.

\section{Counterfactuals for changes in school choice}

The "choice effect" represents the change that occurs in the distribution of students' scores at time $t$ if the structure of the selection procedure for period $t$ ' remains constant, with the other conditions corresponding to period $t$ (i.e. the observable and unobservable characteristics and the returns to those characteristics) being given. In order to do this, we estimate a logit function for each year; a value of 1 (one) is assigned to the case in which a student is enrolled in a public school.

The simulation is for a different school choice and incorporates the estimated parameters $\left(\hat{\lambda}_{j}^{t^{\prime}}\right)$ for period $t^{\prime}$. The procedure for dealing with the error term for this equation consists of calculating a residual as the value of the observed decision ( 1 for enrolment in public schools and 0 for enrolment in private ones), minus the probability indicated by the logit estimation. A family is deemed to prefer public schools if the probability estimated by means of this simulation is equal to or greater than 0.5; if the value is lower than that, it is assumed that the family chooses a private school. Thus, a structure of school choice for individuals in period $t$ can be simulated with parameters representing the structure of school choice that correspond to period $t$ ' while all others refer to period $t$.

In this simulation, the individuals in period $t$ can choose a different type of school from the one they actually attend. After simulating the individuals' school choice in period $t$, the performance corresponding to the simulated situation is imputed to them. In those 
cases in which the result of the simulation changes the choice of school, there is no estimated error term for the production function, so random terms are selected from a normal distribution for those residuals that correspond to the actually observed decisions regarding the type of school.

\section{(a) Complementary factors}

The complementary factors associated with the microsimulation include, first of all, the simulation of unobservable variables. Subgroups by type of institution and the size of the population centre are used for this purpose. One factor is calculated as the fraction corresponding to the standard deviation of the residual

\section{IV}

\section{Results}

\section{Results of the Oaxaca-Blinder (1973) decomposition}

The Oaxaca-Blinder methodology makes it possible to disaggregate the total change in scores over the period 2003-2006 into changes in characteristics and changes in the returns to them. The total change occurring between those two years was 4.6 points and is primarily attributable to the "return effect", which amounts to 11.2 points (see table 1). The magnitude of this effect is substantial, as well as being statistically significant, as it is quite similar to the improvement that would be brought about by one standard deviation increase in the socioeconomic and cultural level of the students' households. This means that the characteristics' efficiency in terms of educational attainment was greater in 2006 than in 2003. However, the characteristics effect is negative, which means that they were more disadvantageous in 2006 than they were in 2003. The characteristics-return effect is the least influential and is negative.

When the effects are separated out among the three groups of explanatory variables and the characteristics of the students, their schools and institutional aspects, these effects can be analysed in greater detail. The negative changes linked to the decline in characteristics mainly have to do with the student-related variables. The Index of Economic, Social and Cultural Status (ESCS), which is constructed by the PISA programme on the basis of variables relating to the family environment, reflects the for each year, by group, and this factor is then multiplied by the residuals for the year 2003 by subgroup. This procedure is used for the residuals of the two production functions, by type of institution.

Then, in order to adjust the factors of expansion, a fraction is calculated that reflects the ratio corresponding to the population represented by the sample in 2006 of a subgroup $m$ (by type of school, size of the population centre, grade and, in the case of public schools, grade repetition), i.e. the sum of the factors of expansion for each subgroup relative to the population represented by the sample in 2003 for the same subgroup. The factor of expansion for each observation of subgroup $m$ in 2003 is then multiplied by this fraction. average 1.8-drop in score points, with its mean shifting from -0.35 to -0.51 during the period under study (see table A.2 in the annex). While this may seem to be a somewhat surprising development in the midst of an economic recovery, there are various possible explanations. One possibility is a shift in enrolment trends whereby more students in the upper socioeconomic stratum could be changing from public to private schools, which would tend to depress the ESCS mean for public schools. In addition, secondary-school coverage has increased, chiefly as a result of greater attendance rates in smaller towns. This means that a segment of the student body that used to leave school at an earlier age (and that is probably socioeconomically disadvantaged) is now staying in school, which could be the reason for the trend seen in the ESCS index during this period. Yet another reason for the ESCS trend could be the large-scale emigration from the country that took place during those years, since many of the emigrants came from the middle and upper-middle socioeconomic strata.

The change in the percentage of students in their third, fourth and fifth years of secondary school accounts for the $0.4,0.5$ and 0.7 reductions, respectively, in the corresponding means. Another factor that could be contributing to the drop in mean scores attributable to the characteristic effect is the increase in the percentage of students who have repeated one or more grades. The only variable that has had a positive (although not statistically significant) effect is the sex of the student. 
TABLE 1

Oaxaca-Blinder decomposition

\begin{tabular}{|c|c|c|c|}
\hline & Characteristics & Return & Characteristics-return \\
\hline \multicolumn{4}{|l|}{ Student-related variables } \\
\hline Sex $($ female $=1)$ & $\begin{array}{c}0.01 \\
(0.30)\end{array}$ & $\begin{array}{l}-3.02 \\
(2.24)\end{array}$ & $\begin{array}{c}0.00 \\
(0.11)\end{array}$ \\
\hline Third year & $\begin{array}{l}-0.40 \\
(0.70)\end{array}$ & $\begin{array}{l}-1.53 \\
(1.28)\end{array}$ & $\begin{array}{c}0.08 \\
(0.15)\end{array}$ \\
\hline Fourth year & $\begin{array}{l}-0.49 \\
(2.35)\end{array}$ & $\begin{array}{r}-12.96 \\
(9.09)\end{array}$ & $\begin{array}{c}0.10 \\
(0.52)\end{array}$ \\
\hline Fifth year & $\begin{array}{l}-0.69 \\
(1.60)\end{array}$ & $\begin{array}{l}-2.22^{*} \\
(1.33)\end{array}$ & $\begin{array}{c}0.17 \\
(0.40)\end{array}$ \\
\hline Behind grade & $\begin{array}{l}-0.10 \\
(0.25)\end{array}$ & $\begin{array}{l}-4.34 \\
(4.11)\end{array}$ & $\begin{array}{l}-0.17 \\
(0.42)\end{array}$ \\
\hline ESCS & $\begin{array}{l}-1.78 * * * \\
(0.57)\end{array}$ & $\begin{array}{l}-0.84 \\
(0.73)\end{array}$ & $\begin{array}{l}-0.39 \\
(0.33)\end{array}$ \\
\hline Subtotal: student-related variables & $\begin{array}{l}-3.46 \\
(2.78)\end{array}$ & $\begin{array}{l}-24.91 * \\
(14.74)\end{array}$ & $\begin{array}{l}-0.21 \\
(0.43)\end{array}$ \\
\hline \multicolumn{4}{|l|}{ School-related variables } \\
\hline Peer effect (ESCS) & $\begin{array}{l}-3.04 * * \\
(1.27)\end{array}$ & $\begin{array}{l}-0.85 \\
(2.69)\end{array}$ & $\begin{array}{l}-0.39 \\
(1.22)\end{array}$ \\
\hline School size & $\begin{array}{l}-0.83 \\
(0.87)\end{array}$ & $\begin{array}{l}-1.76 \\
(6.99)\end{array}$ & $\begin{array}{c}0.32 \\
(1.24)\end{array}$ \\
\hline Student-teacher ratio & $\begin{array}{c}0.57 \\
(0.60)\end{array}$ & $\begin{array}{c}1.92 \\
(10.11)\end{array}$ & $\begin{array}{l}-0.21 \\
(1.10)\end{array}$ \\
\hline Shortages of teaching materials & $\begin{array}{c}1.33 \\
(1.10)\end{array}$ & $\begin{array}{c}5.88 \\
(10.51)\end{array}$ & $\begin{array}{l}-0.67 \\
(1.26)\end{array}$ \\
\hline Shortage of mathematics teachers & $\begin{array}{l}-0.64 \\
(1.09)\end{array}$ & $\begin{array}{l}-3.50 \\
(7.39)\end{array}$ & $\begin{array}{c}0.77 \\
(1.64)\end{array}$ \\
\hline Percentage of certified teachers & $\begin{array}{c}1.54 \\
(1.05)\end{array}$ & $\begin{array}{l}-8.93 \\
(8.38)\end{array}$ & $\begin{array}{l}-1.19 \\
(1.21)\end{array}$ \\
\hline Montevideo and its metropolitan area & $\begin{array}{l}-0.22 \\
(0.30)\end{array}$ & $\begin{array}{c}2.31 \\
(3.08)\end{array}$ & $\begin{array}{l}-0.10 \\
(0.19)\end{array}$ \\
\hline Rural & $\begin{array}{c}0.02 \\
(0.12)\end{array}$ & $\begin{array}{c}0.72 \\
(1.07)\end{array}$ & $\begin{array}{l}-0.03 \\
(0.16)\end{array}$ \\
\hline Subtotal: school-related variables & $\begin{array}{l}-1.27 \\
(2.49)\end{array}$ & $\begin{array}{c}-4.21 \\
(18.23)\end{array}$ & $\begin{array}{l}-1.50 \\
(2.73)\end{array}$ \\
\hline \multicolumn{4}{|l|}{ Institutional variables } \\
\hline Selectivity & $\begin{array}{l}-0.15 \\
(0.32)\end{array}$ & $\begin{array}{l}-0.21 \\
(1.24)\end{array}$ & $\begin{array}{c}0.03 \\
(0.21)\end{array}$ \\
\hline Private & $\begin{array}{c}0.08 \\
(0.17) \\
\end{array}$ & $\begin{array}{l}-2.76 \\
(2.02) \\
\end{array}$ & $\begin{array}{l}-0.15 \\
(0.29) \\
\end{array}$ \\
\hline Subtotal: institutional variables & $\begin{array}{l}-0.07 \\
(0.41)\end{array}$ & $\begin{array}{l}-2.96 \\
(2.14)\end{array}$ & $\begin{array}{l}-0.13 \\
(0.37)\end{array}$ \\
\hline Constant & & $\begin{array}{c}43.31 \\
(26.65)\end{array}$ & \\
\hline Total & $\begin{array}{l}-4.79 \\
(4.49)\end{array}$ & $\begin{array}{l}11.23 * * * \\
(3.22)\end{array}$ & $\begin{array}{l}-1.84 \\
(2.77)\end{array}$ \\
\hline
\end{tabular}

Source: Authors' calculations based on data from the Organisation for Economic Cooperation and Development (OECD), "PISA 2003" and "PISA 2006" [online] http://www.pisa.oecd.org/document/51/0,3746,en_32252351_32235731_39732595_1_1_1_1,00.html

Levels of significance: $* 10 \%, * * 5 \%, * * * 1 \%$

Standard errors are shown in parentheses.

Note: Values are expanded for the entire population.

ESCS: Index of Economic, Social and Cultural Status. 
When looking at the school-related variables, we find that the decrease in the peer effect accounts for a three-point reduction in the characteristics effect, while the decrease in average school size accounts for only 0.8 points of this effect. The decline in the indicator for shortages of teaching materials and the increase in the percentage of certified teachers account for positive changes of 1.3 and 1.5 points, respectively. The total for school-related variables is negative but not statistically significant. Meanwhile, none of the institutional variables proves to be significant; the dummy variable for selectivity is negative, and attendance at private schools is positive.

As for the effects of changes in the efficiency of characteristics (the return effect), the 43.3-point increase in the constant can be accounted for by a recomposition of the cumulative effect of each additional year of schooling (whereby the attainment of students at lower achievement levels improves considerably) and by the broad increase in the school system's coverage of Uruguayan students overall. On the other hand, during this period the learning gap between students who have repeated one or more grades and those who have not done so widened and had a negative effect equivalent to 4.3 points.

As for the returns to school characteristics, the overall change is chiefly accounted for by the decline in effectiveness of the percentage of certified teachers and the shortage of mathematics teachers. Shortages of teaching materials, the student-teacher ratio and the dummy variables, by school location, are positive. The decrease in the return to institutional variables is mainly accounted for by the 2.8-point change in the returns to the choice of a private school.

Thus, the trend in the return effect of the constant reflects a narrower range in the levels of educational attainment, which signals a major advance in educational equity for Uruguayan students. This indicates that the bulk of the improvement seen during this period has been shared by all of the country's students and especially those who attend public schools. This increase in equity has, however, been partially counterbalanced by the decrease in the return to attendance at private schools and the drop in returns to grade level.

The characteristics-return effect is negative but not significant and is mainly accounted for by the trend in this effect relative to the school-related variables.

\section{Results of the Juhn, Murphy and Pierce (1993) decomposition}

In analysing the different effects of the Juhn, Murphy and Pierce decomposition, table 2 shows the values for each of the effects that were included in the study, by decile and by the mean. The total change in the results is positive for the first eight score deciles and negative for the last two, with the greatest change being seen in the second, third and fourth deciles. The characteristics effect is negative for all the deciles of the score distribution, but its absolute magnitude is the greatest for the bottom decile. This result points to a regressive effect that is related to the magnitude of the given characteristics. The results obtained using the Oaxaca-Blinder methodology indicate that this effect is concentrated in variables at the individual level.

Table 2 shows that the total change in results is positive for the first eight score deciles and negative for the last two, with the biggest changes occurring in the second, third and fourth deciles. The characteristics effect is negative for all deciles of the score distribution, but its absolute magnitude is the greatest for the bottom

TABLE 2

Juhn, Murphy and Pierce decomposition

\begin{tabular}{lccccc}
\hline & Change: 2006-2003 & Characteristics effect & Return effect & Residual effect & Characteristics-return effect \\
\hline Mean & 4.60 & -6.62 & 11.23 & 1.92 & -1.93 \\
Decile 1 & 3.85 & -13.24 & 16.48 & 3.49 & -2.88 \\
Decile 2 & 7.19 & -8.59 & 15.04 & 2.98 & -2.24 \\
Decile 3 & 7.34 & -6.94 & 13.40 & 2.72 & -1.83 \\
Decile 4 & 7.72 & -5.74 & 12.54 & 2.95 & -1.02 \\
Decile 5 & 6.47 & -6.13 & 11.05 & 2.63 & -1.75 \\
Decile 6 & 6.62 & -4.55 & 10.72 & 2.20 & -2.25 \\
Decile 7 & 5.22 & -5.48 & 10.18 & 1.78 & -1.60 \\
Decile 8 & 2.81 & -7.22 & 7.90 & 1.33 & -1.72 \\
Decile 9 & -0.16 & -3.77 & 6.48 & -1.93 & -1.90 \\
Decile 10 & -1.13 & & & \\
\hline
\end{tabular}

Source: Authors' calculations based on data from the Organisation for Economic Cooperation and Development (OECD), "PISA 2003" and "PISA 2006" [online] http://www.pisa.oecd.org/document/51/0,3746,en_32252351_32235731_39732595_1_1_1_1,00.html

Note: Values expanded for the entire population. 
decile. This means that there is a regressive impact which is linked to the magnitude of the characteristics in question. The results obtained using the Oaxaca-Blinder methodology indicate that this effect is concentrated in variables at the individual level.

As can be seen from figure 2, the return effect is invariably greater than the total change and is positive, although progressively less so. Table 2 also points to an increase in scores in all the deciles due to a more efficient use of the characteristics in question, with the higher averages being in the first two deciles; this indicates that the impact is progressive.

The residual effect is positive for the first nine deciles but negative for the last one, although it is small in magnitude in all cases. This effect reflects the change in the distribution of unobserved variables in terms of both their magnitude and their returns. The characteristicsreturn effect is negative in all cases and is greater in magnitude in the middle deciles of the distribution.

The results of the application of the Juhn, Murphy and Pierce decomposition are consistent with those obtained with the Oaxaca-Blinder decomposition. Most of the total difference between the 2003 and 2006 PISA scores is attributable to the positive effect of the change in the efficiency of factor use, while the magnitude of the characteristics effect is associated with a negative change that partially offsets the positive impact of the school system's increased efficiency. In other words, the difference between the 2003 and 2006 scores is accounted for by a reduction in available resources and a more efficient use of those resources.

The increase in efficiency signals that the country is moving in the right direction. The reduction in characteristics poses a major challenge for Uruguay's school system, however, since it must find a way of improving the general conditions for students in the system. This is a matter of some urgency, since the gain in the effectiveness of the school system could have enabled underprivileged students to move up a level in terms of their performance on the mathematics test in slightly more than a decade; however, the deterioration in social and economic conditions for this segment of the population during that same decade has had the effect of lengthening the time needed to move up a level to three decades.

\section{Results of the Bourguignon, Fournier and Gurgand (1998) decomposition}

\section{(a) Estimation of production functions}

The first step in conducting the microsimulations is to estimate the production functions for the 2003 and 2006 PISA tests for each type of school (see table 3 ).

The $R^{2}$ in the estimates indicates that it is possible to account for nearly $40 \%$ of the variance in scores in the estimations for public schools, whereas, in the case of

FIGURE 2

\section{Overall effects, Juhn, Murphy and Pierce decomposition}

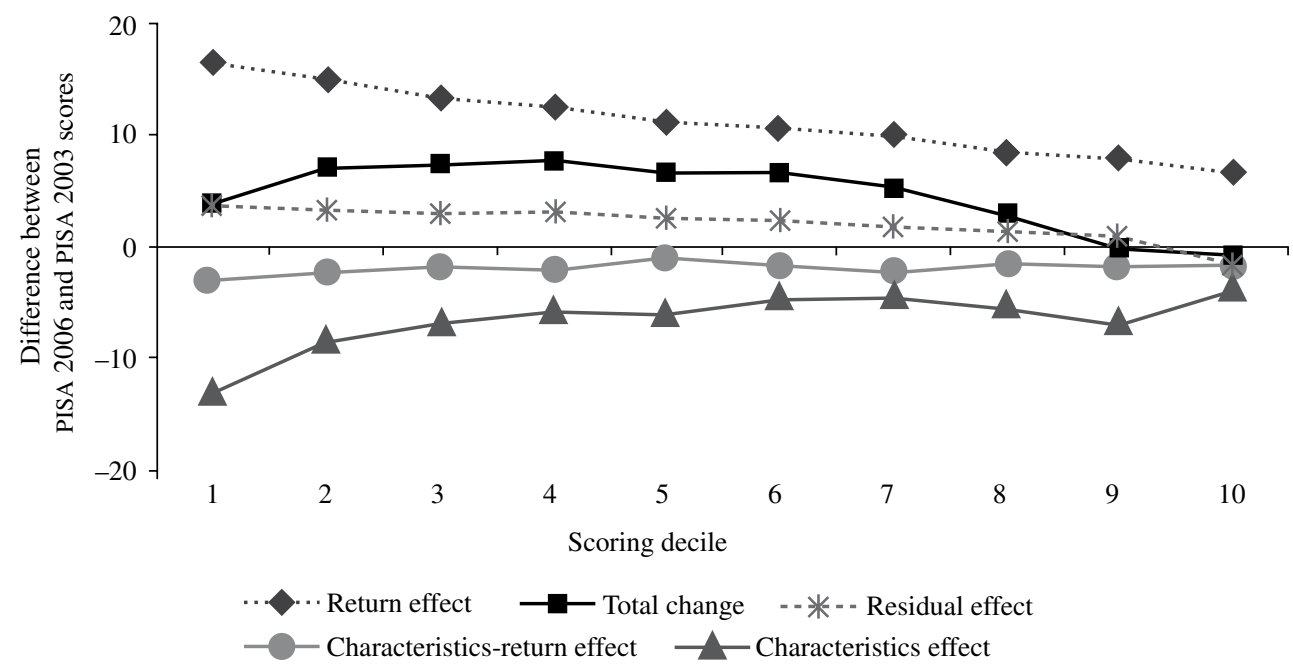

Source: Authors' calculations based on data from the Organisation for Economic Cooperation and Development (OECD), "PISA 2003" and "PISA 2006" [online] http://www.pisa.oecd.org/document/51/0,3746,en_32252351_32235731_39732595_1_1_1_1,00.html 
Estimation of production functions for public and private schools, 2003-2006

\begin{tabular}{|c|c|c|c|c|}
\hline & \multicolumn{2}{|c|}{ Public } & \multicolumn{2}{|c|}{ Private } \\
\hline & 2003 & 2006 & 2003 & 2006 \\
\hline \multicolumn{5}{|l|}{ Student-related variables } \\
\hline Sex $($ female $=1)$ & $\begin{array}{l}-18.13 * * * \\
(3.49)\end{array}$ & $\begin{array}{l}-24.59 * * * \\
(3.75)\end{array}$ & $\begin{array}{l}-21.93^{* * * *} \\
(4.95)\end{array}$ & $\begin{array}{l}-21.31 * * * \\
(5.27)\end{array}$ \\
\hline Third year & $\begin{array}{l}41.89 * * * \\
(4.31)\end{array}$ & $\begin{array}{l}34.76^{* * * *} \\
(5.61)\end{array}$ & $\begin{array}{l}110.40^{* * * *} \\
(39.16)\end{array}$ & $\begin{array}{c}-3.49 \\
(26.79)\end{array}$ \\
\hline Fourth year & $\begin{array}{l}110.00 * * * \\
(9.45)\end{array}$ & $\begin{array}{l}87.38^{* * * *} \\
(12.96)\end{array}$ & $\begin{array}{l}123.80 * * * \\
(33.57)\end{array}$ & $\begin{array}{c}23.49 \\
(37.79)\end{array}$ \\
\hline Fifth year & $\begin{array}{l}140.40 * * * \\
(13.04)\end{array}$ & $\begin{array}{l}106.50 \text { *** } \\
(14.68)\end{array}$ & $\begin{array}{l}148.60 * * * \\
(34.99)\end{array}$ & $\begin{array}{l}44.73 \\
(37.31)\end{array}$ \\
\hline Behind grade & $\begin{array}{l}-5.53 \\
(8.55)\end{array}$ & $\begin{array}{l}-21.56^{* * *} \\
(10.21)\end{array}$ & $\begin{array}{l}-10.75 \\
(21.50)\end{array}$ & $\begin{array}{l}-26.65 \\
(25.42)\end{array}$ \\
\hline ESCS & $\begin{array}{l}10.88 * * * \\
(1.42)\end{array}$ & $\begin{array}{l}12.80 * * * \\
(1.81)\end{array}$ & $\begin{array}{l}12.78 * * * \\
(4.73)\end{array}$ & $\begin{array}{l}16.15^{* * * *} \\
(3.85)\end{array}$ \\
\hline \multicolumn{5}{|l|}{ School-related variables } \\
\hline Peer effect (ESCS) & $\begin{array}{l}14.50 * * \\
(5.93)\end{array}$ & $\begin{array}{l}15.79 * * * \\
(5.51)\end{array}$ & $\begin{array}{l}36.50 * * \\
(18.21)\end{array}$ & $\begin{array}{l}54.98 * * * \\
(10.96)\end{array}$ \\
\hline School size & $\begin{array}{c}0.00 \\
(0.01)\end{array}$ & $\begin{array}{l}-0.01 \\
(0.01)\end{array}$ & $\begin{array}{c}0.01 \\
(0.02)\end{array}$ & $\begin{array}{c}0.01 \\
(0.02)\end{array}$ \\
\hline Student-teacher ratio & $\begin{array}{l}-0.11 \\
(0.31)\end{array}$ & $\begin{array}{l}-0.14 \\
(0.60)\end{array}$ & $\begin{array}{l}-0.31 \\
(1.26)\end{array}$ & $\begin{array}{c}0.24 \\
(0.91)\end{array}$ \\
\hline Shortages of teaching materials & $\begin{array}{l}-2.21 \\
(2.50)\end{array}$ & $\begin{array}{l}-1.39 \\
(2.24)\end{array}$ & $\begin{array}{r}-12.07 \\
(8.63)\end{array}$ & $\begin{array}{l}-7.01 \\
(6.31)\end{array}$ \\
\hline Shortages of mathematics teachers & $\begin{array}{l}1.47 \\
(2.17)\end{array}$ & $\begin{array}{l}-0.61 \\
(2.59)\end{array}$ & $\begin{array}{c}4.62 \\
(6.51)\end{array}$ & $\begin{array}{c}1.28 \\
(5.12)\end{array}$ \\
\hline Percentage of certified teachers & $\begin{array}{c}16.05 \\
(13.99)\end{array}$ & $\begin{array}{l}16.84 \\
(11.84)\end{array}$ & $\begin{array}{c}52.14 * \\
(27.11)\end{array}$ & $\begin{array}{l}-18.33 \\
(16.04)\end{array}$ \\
\hline Montevideo and its metropolitan area & $\begin{array}{l}12.02 * * \\
(4.70)\end{array}$ & $\begin{array}{l}14.14 * * * \\
(4.93)\end{array}$ & $\begin{array}{c}6.87 \\
(13.17)\end{array}$ & $\begin{array}{l}14.55 \\
(14.64)\end{array}$ \\
\hline Rural & $\begin{array}{l}-9.62 \\
(8.43)\end{array}$ & $\begin{array}{l}-5.42 \\
(8.55)\end{array}$ & $\begin{array}{l}20.08 \\
(24.84)\end{array}$ & $\begin{array}{l}0.00 \\
(0)\end{array}$ \\
\hline \multicolumn{5}{|l|}{ Institutional variables } \\
\hline Selectivity & $\begin{array}{c}12.82 \\
(10.32)\end{array}$ & $\begin{array}{c}6.02 \\
(8.34)\end{array}$ & $\begin{array}{c}1.21 \\
(12.18)\end{array}$ & $\begin{array}{c}3.89 \\
(10.87)\end{array}$ \\
\hline Constant & $\begin{array}{l}346.4 * * * \\
(19.36)\end{array}$ & $\begin{array}{l}390.9 * * * \\
(21.09)\end{array}$ & $\begin{array}{l}325.0 * * * \\
(41.02)\end{array}$ & $\begin{array}{l}432.9 * * * \\
(45.19)\end{array}$ \\
\hline $\begin{array}{l}\text { Observations } \\
\mathrm{R}^{2}\end{array}$ & $\begin{array}{r}4679 \\
0.39\end{array}$ & $\begin{array}{r}3826 \\
0.38\end{array}$ & $\begin{array}{l}1156 \\
0.17\end{array}$ & $\begin{array}{l}1013 \\
\quad 0.24\end{array}$ \\
\hline
\end{tabular}

Source: Authors' calculations based on data from the Organisation for Economic Cooperation and Development (OECD), "PISA 2003" and "PISA 2006" [online] http://www.pisa.oecd.org/document/51/0,3746,en_32252351_32235731_39732595_1_1_1_1,00.html

Levels of significance: $* 10 \%, * * 5 \%, * * * 1 \%$

Standard errors are shown in parentheses.

Note: Values expanded for the entire population.

ESCS: Index of Economic, Social and Cultural Status.

private schools, the $R^{2}$ is around $20 \%$. This means that the explanatory value of the estimates is nearly twice as great for public schools as it is for private schools. This is probably because of the make-up of the student bodies in these two sectors and suggests that the proposed model is a more accurate measurement of trends in scores in public institutions.

Most of the coefficients for variables at the student level are significant. The sex coefficient, which is negative and significant in all cases, declined in magnitude over 
the period in question for public schools and rose slightly in the case of private schools. The magnitude of the coefficients for grade-related variables decreased during the period under study for both types of institutions. In the case of private schools, the magnitude and significance of the grade-related coefficients changed considerably between the two years in question, since part of the coefficient for 2006 is incorporated in the constant, which exhibits a difference between 2003 and 2006 of over 100 points; this signals an improvement for the control group.

Additional score points were achieved by persons who are a grade ahead in all cases. The additional inter-grade gain narrowed in public schools while, in private schools, the lead in scores that students in their fourth year of secondary school had over those in their third year was greater in 2006 than in 2003. The effect for those who were behind the grade associated with their age was negative in all cases, but this coefficient declined between the two years for students in both types of schools. The ESCS coefficients for both public and private schools rose.

Most of the school-related variables did not prove to be significant, ${ }^{8}$ whereas the peer effect was not only positive and significant in all cases but also increased over the period under study, rising by nearly $50 \%$ in private schools and by around $9 \%$ in public schools. The ESCS coefficient at the individual level and the peer effect behaved very differently in public schools than they did in private schools. In the former, the peer effect was 1.3 times greater than the ESCS coefficient at the individual level, while in the latter, it was almost 3 times greater. These differences between the public and private sectors generate a greater incentive for increased segregation for private schools, since the maintenance of the entire student body at a given socioeconomic level will make it possible to obtain a "segregation premium".

As for the size of the population centre, the dummy variable associated with Montevideo had a positive and increasing value during the period under study, while the dummy variable for rural areas was negative for public schools and positive for private ones. The institutional selectivity variable declined between 2003 and 2006

\footnotetext{
8 Since some controls were used in the estimations that might have a non-linear effect, the possibility existed that the lack of statistical significance of some of them could be related to a linear specification. School size and grade size were therefore tested for non-linearity, but the results changed very little, with the exception of school size for 2006, where a downward trend is seen for schools with 800 students or more, which are in the minority in the sample.
}

for public schools and did just the opposite in the case of private institutions.

Finally, the value of the constant was always positive and significant, and its coefficient rose in 2006 relative to its 2003 level.

\section{(b) Estimation of choice of type of school}

A logit function was estimated for each year, with a value of 1 corresponding to cases in which the student attends a public school. The results are shown in table 4.

The dummy variable for the sex of the student was negative but not significant as an explanatory variable for the probability of a student attending a public or private school. The effect of being behind grade level, on the other hand, was positive and significant in all cases for the probability of attending a public school and negative for the probability of attending a private one, while the ESCS coefficient was negative for the probability of attending a public educational institution.

The size of the school and the student-teacher ratio had almost no effect on the probability that a student

TABLE 4

Logit estimation for choice of school type, 2003-2006

\begin{tabular}{lcl}
\hline & 2003 & 2006 \\
\hline Sex (female=1) & -0.19 & -0.09 \\
& $(0.15)$ & $(0.10)$ \\
Behind grade & $1.53^{* * *}$ & $1.10^{* * *}$ \\
& $(0.36)$ & $(0.29)$ \\
ESCS & $-1.36^{* * *}$ & $-1.44 * * *$ \\
& $(0.11)$ & $(0.10)$ \\
School size & 0.00 & 0.00 \\
& $(0.00)$ & $(0.00)$ \\
Student-teacher ratio & 0.07 & $0.08^{* *}$ \\
& $(0.05)$ & $(0.04)$ \\
Montevideo and its metropolitan area & $-1.93^{* * *}$ & $-1.71^{* * *}$ \\
& $(0.37)$ & $(0.41)$ \\
Rural & 0.41 & \\
& $(1.42)$ & \\
Constant & $1.35^{* *}$ & $1.29 * *$ \\
& $(0.68)$ & $(0.55)$ \\
\hline Observations & 5835 & 4381 \\
F statistic & 32.95 & 50.18 \\
Prob $>$ F & 0.00 & 0.00 \\
\hline
\end{tabular}

Source: Authors' calculations based on data from the Organisation for Economic Cooperation and Development (OECD), "PISA 2003" and "PISA 2006" [online] http://www.pisa.oecd.org/document/51/0 ,3746,en_32252351_32235731_39732595_1_1_1_1,00.html

Levels of significance: $* 10 \%, * * 5 \%, * * * 1 \%$

Standard errors are shown in parentheses.

Value $1=$ Public education.

Note: Values expanded for the entire population.

ESCS: Index of Economic, Social and Cultural Status.

Prob > F: p value associated with F statistic, used to test the null hypothesis that all of the model's coefficients are 0. 
would attend a public school. The variables related to the size of the population centre indicate that residence in Montevideo has a significant negative effect in terms of the probability of attending a public school, while residence in a rural area was not a significant factor in 2003. ${ }^{9}$

These findings indicate that students in public schools tend to come from poorer families, be less successful academically and live in smaller cities or towns.

\section{Results of the microsimulations}

The main results of the microsimulations are summed up in table 5. The table provides information on the effects of changes both in the means and in the different score deciles as a result of the difference between the simulated distribution for each case and the observed distribution in 2003. Table A.3, in the annex, shows what the effects are when changes in the type of school are the only factor that is considered.

\section{(a) The characteristics effect}

The characteristics effect, as a whole, has the strongest positive impact of all in terms of explaining the reasons for the overall change in PISA mathematics scores between 2003 and 2006. On average, if schools had had the same individual resource endowments in

\footnotetext{
9 The corresponding coefficient for 2006 is unavailable because the sample for that year does not provide observations for private schools in rural areas.
}

2003 that they had in 2006, their scores would have been 9.2 points higher (see table 5).

A word of caution is called for here with regard to the correct interpretation of this effect. The simulation of characteristics for 2006 entails using the unweighted percentage of cases in which a given characteristic is displayed, in the case of the dichotomous or categorical variables, or the unweighted mean, in the case of the continuous variables. In addition, in calculating the characteristics effect, the distribution measurements are computed using the sample weighting for 2003, which, as will be discussed in greater detail below, differs a great deal from the weighting for 2006, since the samples for those two years were designed very differently. An accurate interpretation of the trend in available resources during this period should therefore include not only the simulation of the characteristics (weighted by the factor of expansion for 2003), but also the weighting for the sample for the year corresponding to the simulation. It then becomes possible to see what happens when only the characteristics for 2006 are simulated and then to compare that result with the result of a simulation that includes the sample weightings for that year and that consequently provides a more accurate picture of the population which is being simulated.

The characteristics effect is greater for the bottom deciles and decreases in the upper deciles. This signals the presence of a redistributive effect, since lower-performing students benefit. If this effect is differentiated by type of school in the simulations for 2006 (see table A.3 in the annex), it turns out that the sharpest change is seen

TABLE 5

Average microsimulation results and microsimulation results by scoring decile, 2003-2006

\begin{tabular}{|c|c|c|c|c|c|c|c|c|c|c|c|}
\hline & Mean & 1 & 2 & 3 & 4 & 5 & 6 & 7 & 8 & 9 & 10 \\
\hline PISA mathematics test -2003 & 422.20 & 257.03 & 318.07 & 355.44 & 384.22 & 410.99 & 435.48 & 460.99 & 489.39 & 523.25 & 587.56 \\
\hline PISA mathematics test -2006 & 426.80 & 260.88 & 325.26 & 362.79 & 391.94 & 417.46 & 442.10 & 466.22 & 492.20 & 523.09 & 586.43 \\
\hline Total difference in PISA mathematics score (2006-2003) & 4.60 & 3.85 & 7.19 & 7.34 & 7.72 & 6.47 & 6.62 & 5.22 & 2.81 & -0.16 & -1.13 \\
\hline Characteristics effect & 9.24 & 13.07 & 17.87 & 15.48 & 13.40 & 10.77 & 8.50 & 5.23 & 2.98 & 2.43 & 2.85 \\
\hline Weight effect & -2.76 & -4.31 & -5.02 & -3.91 & -3.02 & -3.06 & -2.59 & -2.04 & -1.86 & -1.06 & -0.67 \\
\hline Characteristics+weight effect & -2.11 & 0.50 & 0.77 & -0.11 & -1.53 & -2.66 & -2.76 & -4.37 & -6.07 & -4.31 & -0.64 \\
\hline Price effect & 7.69 & 13.24 & 12.15 & 10.37 & 9.21 & 7.44 & 6.91 & 6.12 & 4.67 & 3.90 & 2.67 \\
\hline Characteristics+weight+price effect & 7.59 & 17.40 & 16.54 & 12.63 & 10.22 & 7.51 & 4.42 & 2.93 & 0.35 & 0.97 & 2.86 \\
\hline Choice effect & -0.05 & -0.03 & 0.02 & 0.04 & -0.03 & -0.01 & -0.03 & -0.01 & -0.02 & -0.02 & -0.29 \\
\hline Characteristics+weight+price+choice effect & 5.91 & 9.90 & 10.11 & 7.61 & 7.22 & 6.22 & 5.60 & 4.08 & 2.74 & 2.39 & 3.20 \\
\hline Residual effect & 0.00 & 2.58 & 1.62 & 1.09 & 1.07 & 0.68 & 0.28 & 0.05 & -0.92 & -2.03 & -4.38 \\
\hline Characteristics+weight+price+choice+residual effect & 5.93 & 13.53 & 11.63 & 8.44 & 7.89 & 6.50 & 5.90 & 4.21 & 2.00 & 0.65 & -1.18 \\
\hline
\end{tabular}

Source: Authors' calculations based on data from the Organisation for Economic Cooperation and Development (OECD), "PISA 2003" and "PISA 2006" [online] http://www.pisa.oecd.org/document/51/0,3746,en_32252351_32235731_39732595_1_1_1_1,00.html

Note: Values expanded for the entire population.

Choice effect: School selection effect. 
in public schools (8.4 points) and that this accounts for virtually all of the characteristics effect, since private schools account for just 0.8 points.

Table A.4 (see the annex) provides a detailed look at the characteristics effect for each variable in the model and for the defined groups of variables, disaggregated by type of school. As can be seen from the table, the increase in educational resources is concentrated in the individual variables ( 7 points) and relates mainly to the number of students in their fourth year and to public schools, as well as being greater in the upper deciles of the distribution. The behind-grade variable also exhibits a positive although small effect. The dummy variable for the sex of the student, as well as the other grades and ESCS, points to a negative effect in the trend of scores on the PISA mathematics test.

The variables relating to educational institutions account for a positive change of 2.3 score points, with one of the most influential variables being the percentage of certified teachers (1.6 points). The associated peer effect shows a positive change of 0.2 points, while the ESCS has a negative but nearly negligible effect at the individual level. The student-teacher ratio, shortages of teaching materials and the dummy variable associated with Montevideo also have a positive effect, whereas school size, shortages of mathematics teachers and the dummy variable associated with rural zones exhibit a negative effect. The same is true of the institutional variable of selectiveness, which has a negative effect (see table A.4).

\section{(b) Weight effect}

When the individual weights in the 2003 sample are adjusted to reflect the 2006 population, the total change in PISA scores amounts to a 2.8-point decline (see table 5). This effect is explained chiefly by the change made in the sample design. In the case of Uruguay, a number of changes in the design of the different strata were made between the 2003 and 2006 tests. For the analysis of the 2003 test, 8 strata were used to define the sample design, whereas, for the 2006 test, 16 strata were used. There were also changes in the schools' response rate and in the number and types of schools that did not apply them or that did so incorrectly (ANEP, 2007b). In addition, as noted earlier, the attendance rates for the 2003 and 2006 tests differed, especially in the smaller towns. All of these factors generate variations in the sample weights that account for the size of the weight effect obtained in microsimulations.

The negative weight effect is greater in the first deciles of the distribution; this is accounted for primarily by the change in the weighting of public schools (see table A.3 in the annex).

\section{(c) The characteristics-weight effect}

When the change in characteristics is combined with the change in weights (see the third simulation in table 5 ), the average effect diminishes, but retains the negative sign of the weight effect (-2.1 points). The change in this result, which is attributable to the inter-year variability of the sample weight and to the modification of the sample design, appears to be an accurate reflection of the trend in available resources during the period in question.

When this effect is analysed by decile, it can be seen that it has a positive sign for the first two deciles in the distribution but is negative for the other eight; consequently, the overall effect is highly redistributive. As is also true of the weight effect alone, the combination of these two effects is negative for public schools and positive for private ones.

\section{(d) Return effect}

The return effect is derived from the simulation of the 2006 coefficients in the 2003 score distribution. As shown in table A.5, the total effect of this component amounts to an increase of 7.7 points and is positive for all of the deciles of the distribution; the fact that it is stronger in the first few deciles indicates that it is redistributive. The sign of this effect reflects an increase in the efficiency of these characteristics in public schools, while it is negative for private schools (see table A.3).

Separate analyses of the return effect of each of the variables in the production function (see table A.5) show that the main factor is the greater effectiveness of the constant, which amounts to 53.4 points and signals a widespread improvement in student efficiency.

The combined effect of the variables at the individual, school and institutional levels is negative. This is consistent with the result obtained using the Oaxaca-Blinder decomposition. The increase in the efficiency of the peer effect (1.3 points) is notable, while the effectiveness of the EsCs at the individual level is lower. The bulk of the increase in the peer effect is accounted for by private schools, as the effectiveness of this factor in public schools declined.

Other variables at the school level that have a positive impact on the return effect are the student-teacher ratio, shortages of teaching materials and region-dependent variables. The size of the school, shortages of mathematics teachers and the percentage of teachers who are certified all have a negative effect. The institutional variable of academic selectivity also has a negative effect. 
The overall effect of the variables at the student level is -36.5 points, with the public sector accounting for the majority of this value (-22.6 points). Of the variables at the individual level, the biggest change is generated by the dummy variable for the fourth year of secondary school (-22.5), which has a greater negative impact in the higher deciles of the distribution. All the other variables at the individual level have a negative, although smaller, return effect. The institutional variable of selectivity also has a negative effect.

\section{(e) The characteristics-return effect}

Figure 3 illustrates the combined effect of the change in characteristics and returns for all deciles in the distribution. As indicated by the graph, this effect is positive for the entire distribution and stronger for the lower deciles.

\section{(f) The characteristics-return-weight effect}

The fifth simulation in table 5 shows the combined effect of the simulation of characteristics, returns and weights. In this case, the mean effect is weaker than it is in the simulation of characteristics and returns alone (7.6 points). The combined effect is stronger for the lower deciles in the distribution, which, here again, indicates that it is redistributive. When the change is analysed by type of school (see table A.3 in the annex), it is seen that it is greater for public schools.

\section{(g) The school choice effect}

The school choice effect is negative on average and very close to zero (0), as may be seen from table 5 . It is nearly equal for all the deciles of the distribution.

(h) The characteristics-return-choice-weight effect When a combined simulation of characteristics, returns, school choice and weights is conducted, the mean effect falls to 5.9 points (see table 5), with the greatest decreases relative to the previous combined simulation being in the lower deciles of the distribution (see figure 4). In this case, the sign of this combined effect is positive for public schools and negative for private ones.

\section{(i) Residual effect}

The effect of simulating residuals for 2006 in the 2003 distribution is, on average, nil (see table 5), and this is true for both types of institutions (see table A.3 in the annex). The residual effect varies by decile, however, being positive in the first seven and negative in the last three.

FIGURE 3

Combined effects, by scoring decile

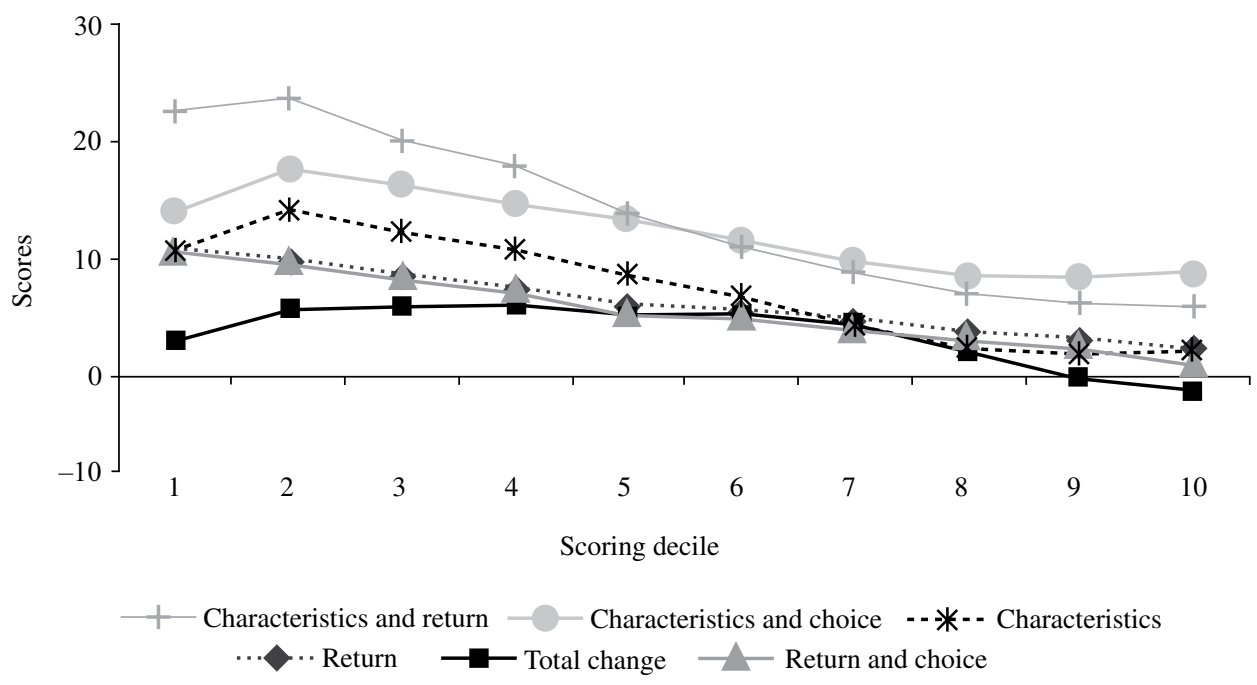

Source: Authors' calculations based on data from the Organisation for Economic Cooperation and Development (OECD), “PISA 2003” and "PISA 2006" [online] http://www.pisa.oecd.org/document/51/0,3746,en_32252351_32235731_39732595_1_1_1_1,00.html

Choice effect: School selection effect. 
FIGURE 4 All effects, by scoring decile

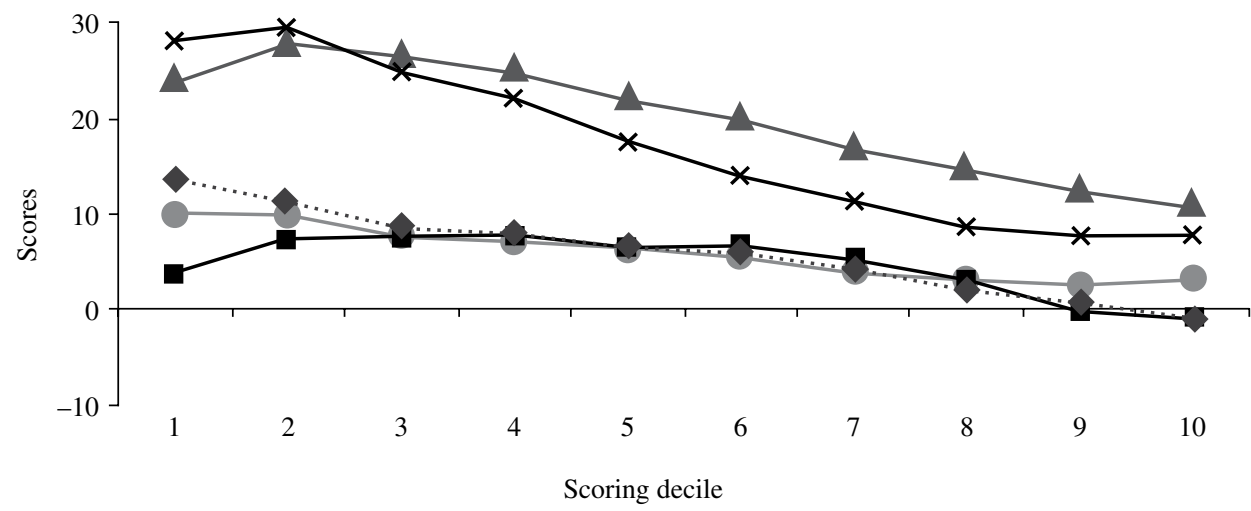

- Total change $\rightarrow$ Characteristics and return
- Characteristics, return, choice and weight $\quad \cdots \rightarrow$ Characteristics, return and choice
- Chistics, return, choice, weight and residual

Source: Authors' calculations based on data from the Organisation for Economic Cooperation and Development (OECD), "PISA 2003" and "PISA 2006" [online] http://www.pisa.oecd.org/document/51/0,3746,en_32252351_32235731_39732595_1_1_1_1,00.html

Choice effect: School selection effect.

\section{(j) Combined effects of the microsimulations}

The overall effect of the microsimulations (see the final simulation in table 5) is a small change in the mean, with a slight decrease in inequality. The progressive nature of the overall change is accounted for by the result for public schools. ${ }^{10}$ The results also show that scores improve only in those schools, since the trend is negative for private schools (see table A. 3 in the annex). The main area of progress is the widespread improvement in the efficiency of resource use. This improvement is, however, offset by a reduction in available resources.

When unobservable variables are included in the first four simulations, it becomes possible to explain a great deal of the inequality seen in the trend in average scores. The overall effect is more positive in the lower deciles and turns negative in the last two. This result is in keeping with the progressive impact of the residual effect obtained using the methodology developed by Juhn, Murphy and Pierce.

The Gini inequality index, the Theil index and the entropy index, which are generally used to analyse trends

\footnotetext{
${ }^{10}$ If the combined effect of the microsimulations, by score decile, is calculated separately for the different types of schools, it turns out to be progressive for public schools and regressive for private schools. These results are in keeping with the total change seen in scores by type of institution.
}

in income distribution, are then used to look at the trend in the size of the reduction in the inequality of the results. As can be seen from table A.6 in the annex, the trend in these three indicators reflects a small decline in levels of inequality in scores on the mathematics test. This reduction amounts to between $0.1 \%$ and $0.4 \%$ of these indicators and is mainly attributable to the progressive effect of the characteristics and price simulation and, in particular, to the change in public schools. The residual effect also has a progressive impact on the level of inequality, although a weaker one. The combined effect of all the simulations corresponds to a $0.8 \%$ decrease on the Gini index and one of $0.3 \%$ on the Theil and entropy indexes.

When all the simulations are combined, the mean effect amounts to 5.9 points (of 4.6, which is the observed change). The total adjustment is more precise for the last deciles in the distribution and is less so for the first decile (see figure 4). The 2006 sample design is more complex and results in a sample that provides a more exact reflection of the student population in the relevant age group; consequently, when the weights for that year are simulated in the 2003 sample (together with the characteristics, returns, school choice and residuals), they explain the changes seen in $90 \%$ of the distribution, thereby making it possible to clearly identify the main factors associated with the trend in each one of the deciles of the score distribution. 


\section{V}

\section{A comparison of the results}

These three methodologies yield mutually consistent results. They complement each other in terms of the degree of complexity of the analysis, and each has its own value-added.

The results obtained from the application of the Oaxaca-Blinder methodology indicate that the total score change is chiefly accounted for by a widespread increase in the efficiency with which the school system makes use of the available resources. The increase in the return to the constant is the main explanatory factor for this increase in efficiency. The fact that this increase was seen across the student population -and was especially marked in public schools- points to a more even distribution of educational outcomes. The improvement is primarily attributable to the economic recovery that occurred during the period under study. This positive effect is weakened somewhat by a lower level of efficiency in the most important variables at the student and school levels, however, especially in the returns to the different grade levels.

The defined characteristics were more disadvantageous in 2006 than in 2003, and most of this effect is concentrated in student-related variables. Although this marks a contrast with the economic recovery

\section{VI}

\section{Conclusions}

This study provides information on the differences in the distribution of the PISA mathematics scores for 2003 and 2006 and identifies factors underlying those changes and the trend in their effects over the period under study. An analysis of the results obtained using three different methodologies leads to mutually consistent conclusions that support the statement that the country's outcomes, in terms of both equity and scores, are unsatisfactory.

A first conclusion is that, although the change seen between the results for the 2003 and 2006 tests is very small and has little impact in terms of an improvement in Uruguayan students' performance on the mathematics tests, there have been underlying changes in the defined characteristics and returns that offset one another, thereby of those years, it may be due to various factors, such as changes in enrolment or the demographic changes occurring in the country during that time.

The methodology developed by Juhn, Murphy and Pierce also makes it possible to draw conclusions about the influence exerted by the various effects on the different deciles of the distribution and indicates that there has been a progressive impact as a result of the return effect.

The microsimulations provide a way of gauging the extent of the differences existing between students in public and private schools, and they indicate that the change observed during the period under study was accounted for solely by students in State-run schools. The estimates also indicate just how sensitive the results are to changes in the composition of the samples. The characteristics effect is shown to be positive when the microsimulations are run, which differs from the results obtained with the other two decomposition techniques. When the simulation of the sample weighting is added in, however, the overall effect proves to be negative and of a similar strength as that calculated earlier using the Oaxaca-Blinder and the Juhn, Murphy and Pierce methodologies. yielding a very small overall change. This bears out the study's initial hypothesis.

Secondly, the evidence suggests that the improvement in scores in 2006 relative to 2003 is attributable to an increase in the education system's ability to convert educational resources and characteristics into learning outcomes and, in particular, to a widespread efficiency gain in the use made of resources generated by the economic recovery of that period. This was especially marked in public schools, although it was partially offset by a decrease in the efficiency of grade-related factors at the individual level.

Thirdly, there was a reduction in resource endowments, particularly at the student level. This 
decrease was especially notable in terms of socioeconomic and cultural characteristics and in the percentage of students at the higher grades (above all in the case of the more disadvantaged students). This indicates that the deterioration in the family- and school-related circumstances associated with students in the most vulnerable groups of the population has had the effect of making it take longer for these young people to move up from one step to the next on the scale used by the PISA test to measure proficiency in mathematics. If this had not been the case, this group was projected to have reached that objective in slightly more than a decade, whereas, with the emergence of these two groups of factors, it will take between 25 and 30 years to reach that goal.

Finally, the improvement in the scores on the PISA mathematics test had a redistributive effect and was concentrated among lower-performing students. This finding reflects a reduction in test-score dispersion and is accounted for by trends in the country's public schools.

Economic growth ought to be closely related to a substantive improvement in performance, but such a relationship is not evident in the scores obtained by Uruguayan students during this period. This indicates that the deterioration in social and economic conditions that occurred at the start of the decade brought about a structural decrease in educational opportunities for young students, while the benefits of the recovery will probably not become evident until the results of the 2012 PISA test are in. The methodologies used in this study offer a means of undertaking an in depth analysis into the challenges and situations faced by Uruguayan students and of identifying ways of enabling the country to meet its obligation to provide a satisfactory education to all of its citizens. The data lead to the conclusion that efforts should be focused on mobilizing educational resources and boosting efficiency at the individual level. Policies designed to provide more support for socioculturally disadvantaged students are of critical importance in reducing the high rate of grade repetition and in seeking ways of providing higher returns to each additional year of schooling.

Despite the drop in the ESCS coefficient, the mean score for this period rose and, although the increase was slight overall, it was considerable in the lower-middle and middle strata. This would appear to indicate that, following the economic shock experienced by the country (which hit the vulnerable groups in society the hardest, not only in economic terms but also in terms of opportunities for social mobility, including those afforded by education) in 2003-2006, the potential retrogression triggered by the crisis appears to have been reversed. Nonetheless, formidable challenges remain to be overcome in order to improve the school system's overall effectiveness, particularly since the headway that was made in 20032006 could simply be due to the recovery rather than to increased effectiveness on the part of the school system. If this proves to have been the case, then we may not see further improvements in scores on future PISA tests, as occurred in 2009.

This study paves the way for the use of these methodologies to analyze the 2009 PISA scores as a means of delving more deeply into the underlying reasons for Uruguayan students' performance on this test. The incorporation of the more recent data will make it possible to analyse the trends of the last few years, which have been marked by economic growth and reforms aimed at improving the education imparted by the country's schools while also making it more equitable. This type of analysis could also be expanded to include comparisons of the results obtained by Uruguay with those of other countries at similar socioeconomic levels, such as Chile or Argentina, and with the scores of countries that have succeeded in making much greater gains, such as Poland.

(Original: Spanish) 
ANNEX

TABLE A. 1

Selected variables

\begin{tabular}{|c|c|}
\hline Variable used & Comments \\
\hline \multicolumn{2}{|l|}{ Results variable } \\
\hline Mathematics score & 2003-2006 PISA scores, 5 plausible values for performance on the mathematics test \\
\hline \multicolumn{2}{|l|}{ Student-related variables } \\
\hline Sex & Dummy variable for sex of student (omitted category: male) \\
\hline Grade & $\begin{array}{l}\text { Five dummy variables for a student's current grade: grade } 7 \text { (first year of secondary school), } \\
\text { grade } 8 \text { (second year), grade } 9 \text { (third year), grade } 10 \text { (fourth year), grade } 11 \text { (fifth year) } \\
\text { (omitted categories: any grade other than those grades) }\end{array}$ \\
\hline Behind grade & $\begin{array}{l}\text { Dummy variable that indicates whether the student has repeated a grade (omitted category: } \\
\text { no repetition) }\end{array}$ \\
\hline $\begin{array}{l}\text { Index of Economic, Social and } \\
\text { Cultural Status (ESCS) }\end{array}$ & $\begin{array}{l}\text { Variable developed by OECD/PISA which takes into consideration the education and occupation } \\
\text { of the parents and the types of products or goods in the home. Mean of } 0 \text { and standard } \\
\text { deviation of } 1 \text { for the OECD-country average. A higher ranking on the index indicates a higher } \\
\text { socioeconomic level }\end{array}$ \\
\hline
\end{tabular}

School-related variables

Peer effect

School size

Student-teacher ratio

Shortages of teaching materials

Shortages of qualified mathematics teachers

Percentage of certified teachers

Size of population centre
Variable that measures the average Escs rank for students in the same school

Continuous variable that indicates the average number of students who are enrolled

Continuous variable that indicates the average student-teacher ratio

Variable that indicates the extent to which the school's ability to educate its students is undermined by shortages of suitable teaching materials: Scale ranges from 1 to 4

Variable that indicates the extent to which the school's ability to educate its students is undermined by shortages of qualified mathematics teachers: Scale ranges from 1 to 4

Variable that indicates the percentage of the schools' teachers who are certified: Scale ranges from 0 to 1

Four dummy variables that indicate the location of the school: Montevideo and the surrounding metropolitan area, major cities elsewhere in the country, smaller cities, rural areas (omitted categories: does not live in that population centre)

Institutional variables

Academic selectivity

Public secondary school

Dummy variable that indicates whether or not a school applies selective criteria in reaching admissions decisions (based on the school selectivity index developed by OECD/PISA (omitted category: does not apply)

Private secondary school

Dummy variable that indicates whether or not the school is a public secondary school (general, military, rural or technical) (omitted category: does not correspond)

Dummy variable that indicates whether or not the school is a private secondary school (omitted category: does not correspond)

Source: Authors' calculations. 
Descriptive statistics, 2003-2006

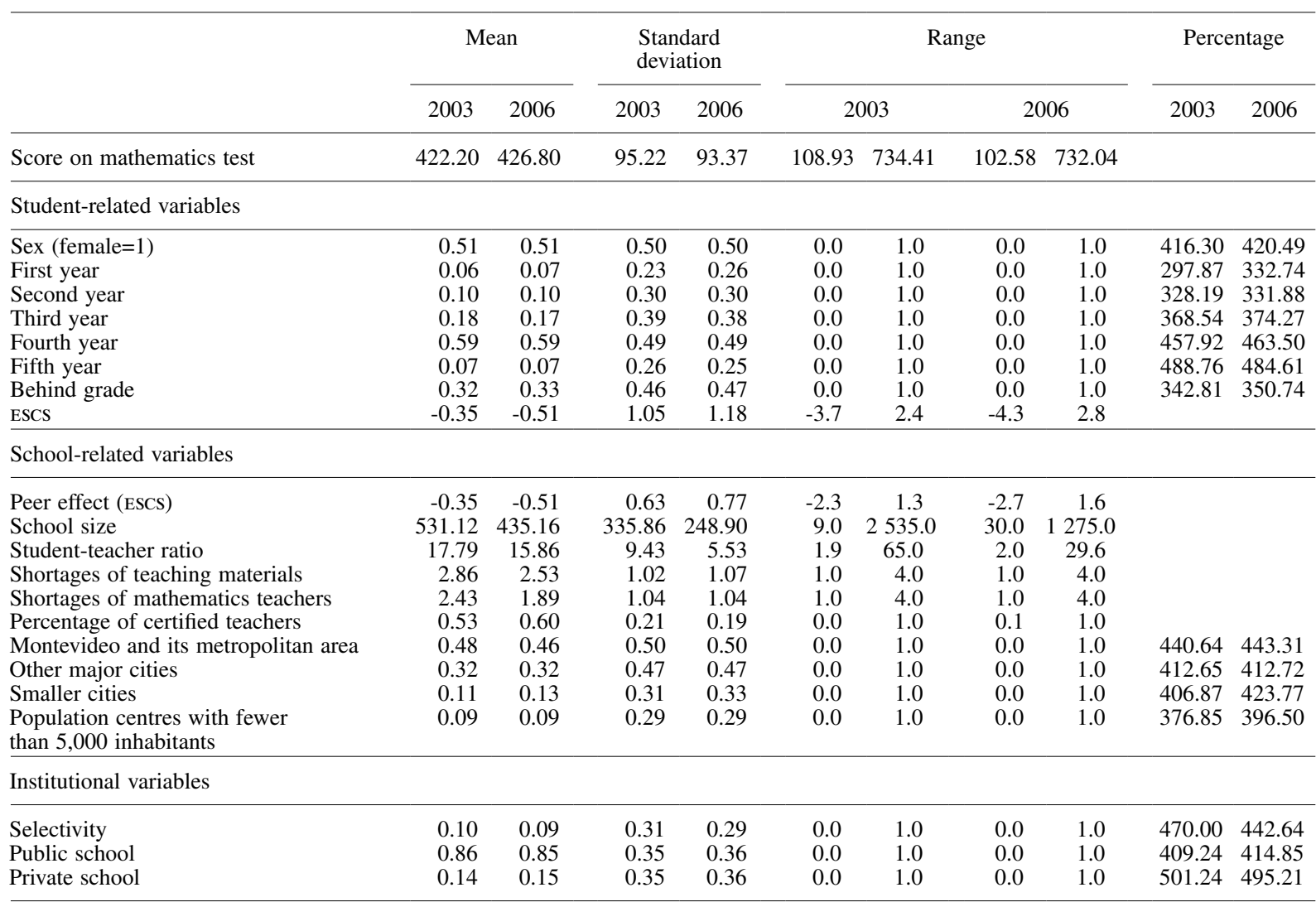

Source: Authors' calculations based on data from the Organisation for Economic Cooperation and Development (OECD), "PISA 2003" and "PISA 2006" [online] http://www.pisa.oecd.org/document/51/0,3746,en_32252351_32235731_39732595_1_1_1_1,00.html

Note: Values expanded for the entire population.

ESCS: Index of Economic, Social and Cultural Status.

TABLE A. 3

Results of microsimulations with changes in one type of school, 2003-2006

\begin{tabular}{|c|c|c|c|}
\hline & \multirow{2}{*}{ Average total effect } & \multicolumn{2}{|c|}{ Changes only in: } \\
\hline & & Public & Private \\
\hline $\begin{array}{l}\text { PISA mathematics test: } 2003 \\
\text { PISA mathematics test: } 2006\end{array}$ & $\begin{array}{l}422.20 \\
426.80\end{array}$ & & \\
\hline Total difference in PISA mathematics score & 4.60 & & \\
\hline Characteristics + weight + price + choice + residual effect & 5.93 & 6.58 & -0.93 \\
\hline
\end{tabular}

Source: Authors' calculations based on data from the Organisation for Economic Cooperation and Development (OECD), "PISA 2003" and "PISA 2006" [online] http://www.pisa.oecd.org/document/51/0,3746,en_32252351_32235731_39732595_1_1_1_1,00.html

Note: Values expanded for the entire population. 
Results of the microsimulations of characteristics per scoring decile, 2003-2006

\begin{tabular}{|c|c|c|c|c|c|c|}
\hline & \multicolumn{4}{|c|}{ Total effect and effect by decile $(X)$} & \multicolumn{2}{|c|}{ Changes only in: } \\
\hline & Total & 2 & 5 & 9 & Public & Private \\
\hline PISA mathematics test -2003 & 422.20 & 318.07 & 410.99 & 523.22 & & \\
\hline PISA mathematics test -2006 & 426.80 & 325.26 & 417.46 & 523.09 & & \\
\hline Total difference in PISA mathematics score & 4.60 & 7.19 & 6.47 & -0.13 & & \\
\hline Student-related variables & 7.05 & 17.05 & 8.17 & -1.18 & 6.85 & 0.20 \\
\hline Sex $($ female $=1)$ & -1.82 & 2.23 & -2.99 & -4.05 & -1.84 & 0.03 \\
\hline Third year & -1.99 & -4.79 & -2.46 & -0.13 & -2.13 & 0.14 \\
\hline Fourth year & 11.94 & 7.00 & 7.92 & 18.74 & 11.60 & 0.34 \\
\hline Fifth year & -1.25 & -1.05 & -2.19 & -1.46 & -0.76 & -0.49 \\
\hline Behind grade & 0.33 & 1.95 & 0.06 & -0.61 & 0.33 & 0.00 \\
\hline ESCS & -0.15 & -0.83 & -0.34 & 0.57 & -0.34 & 0.19 \\
\hline School-related variables & 2.29 & -0.32 & 2.25 & 4.74 & 1.67 & 0.62 \\
\hline Peer effect (ESCS) & 0.25 & -1.20 & 0.01 & 1.72 & -0.28 & 0.53 \\
\hline School size & -0.02 & 0.01 & -0.10 & -0.04 & -0.01 & -0.01 \\
\hline Student-teacher ratio & 0.16 & 0.11 & 0.12 & 0.27 & 0.13 & 0.03 \\
\hline Shortages of teaching materials & 1.00 & 0.18 & 0.75 & 1.78 & 0.76 & 0.24 \\
\hline Shortages of mathematics teachers & -0.91 & -0.76 & -0.98 & -0.98 & -0.87 & -0.04 \\
\hline Percentage of certified teachers & 1.63 & 1.98 & 1.64 & 1.39 & 1.70 & -0.06 \\
\hline Montevideo and its metropolitan area & 0.26 & -0.42 & 0.42 & 1.00 & 0.26 & 0.00 \\
\hline Rural & -0.08 & -0.14 & -0.06 & 0.27 & -0.01 & -0.07 \\
\hline Institutional variables & -0.09 & 0.36 & -0.25 & 0.14 & -0.07 & -0.02 \\
\hline Selectivity & -0.09 & 0.36 & -0.25 & 0.14 & -0.07 & -0.02 \\
\hline Student-related and school-related variables & 9.34 & 17.87 & 10.71 & 2.82 & 8.52 & 0.82 \\
\hline Student-related and institutional variables & 6.96 & 17.04 & 8.16 & -1.32 & 6.78 & 0.18 \\
\hline School-related and institutional variables & 2.19 & 0.03 & 1.89 & 4.51 & 1.59 & 0.60 \\
\hline All variables & 9.24 & 17.87 & 10.77 & 2.46 & 8.45 & 0.80 \\
\hline
\end{tabular}

Source: Authors' calculations based on data from the Organisation for Economic Cooperation and Development (OECD), "PISA 2003" and "PISA 2006" [online] http://www.pisa.oecd.org/document/51/0,3746,en_32252351_32235731_39732595_1_1_1_1,00.html

Note: Values expanded for the entire population.

ESCS: Index of Economic, Social and Cultural Status.

TABLE A. 5

Results of microsimulations of coefficients per scoring decile, 2003-2006

\begin{tabular}{|c|c|c|c|c|c|c|}
\hline & \multicolumn{4}{|c|}{ Total effect and effect by decile $(\beta)$} & \multicolumn{2}{|c|}{ Changes only in: } \\
\hline & Total & 2 & 5 & 9 & Public & Private \\
\hline PISA mathematics test -2003 & 422.20 & 318.07 & 410.99 & 523.25 & & \\
\hline PISA mathematics test -2006 & 426.80 & 325.26 & 417.46 & 523.09 & & \\
\hline Total difference in PISA mathematics score & 4.60 & 7.19 & 6.47 & -0.16 & & \\
\hline Student-related variables & -36.54 & -29.29 & -35.38 & -43.09 & -22.63 & -13.91 \\
\hline Sex $($ female $=1)$ & -2.80 & -3.33 & -3.17 & -2.09 & -2.85 & 0.04 \\
\hline Third year & -2.41 & -3.67 & -2.57 & -1.60 & -1.22 & -1.19 \\
\hline Fourth year & -22.50 & -11.91 & -22.54 & -32.44 & -10.81 & -11.69 \\
\hline Fifth year & -3.25 & -1.04 & -3.36 & -5.61 & -1.99 & -1.26 \\
\hline Behind grade & -5.05 & -11.62 & -4.31 & -0.47 & -4.89 & -0.16 \\
\hline ESCS & -0.52 & -1.55 & -0.88 & 0.66 & -0.87 & 0.34 \\
\hline
\end{tabular}




\begin{tabular}{|c|c|c|c|c|c|c|}
\hline & \multicolumn{4}{|c|}{ Total effect and effect by decile $(\beta)$} & \multicolumn{2}{|c|}{ Changes only in: } \\
\hline & Total & 2 & 5 & 9 & Public & Private \\
\hline School-related variables & -8.87 & -6.77 & -8.65 & -10.89 & -6.31 & -2.56 \\
\hline Peer effect (ESCS) & 1.29 & -0.84 & 0.39 & 3.80 & -0.58 & 1.87 \\
\hline School size & -4.25 & -3.73 & -4.65 & -4.40 & -4.24 & -0.01 \\
\hline Student-teacher ratio & 0.61 & -0.42 & 0.08 & 1.96 & -0.51 & 1.12 \\
\hline Shortages of teaching materials & 3.27 & 2.47 & 3.00 & 4.09 & 2.15 & 1.11 \\
\hline Shortages of mathematics teachers & -5.32 & -5.10 & -5.32 & -5.60 & -4.64 & -0.68 \\
\hline Percentage of certified teachers & -6.45 & -1.50 & -4.54 & -11.42 & 0.34 & -6.79 \\
\hline Montevideo and its metropolitan area & 1.67 & 0.79 & 1.30 & 2.55 & 0.77 & 0.90 \\
\hline Rural & 0.30 & 0.71 & 0.24 & 0.18 & 0.38 & -0.07 \\
\hline Institutional variables & -0.26 & -0.28 & -0.37 & -0.09 & -0.39 & 0.13 \\
\hline Selectivity & -0.26 & -0.28 & -0.37 & -0.09 & -0.39 & 0.13 \\
\hline Constant & 53.36 & 45.28 & 48.93 & 64.49 & 38.16 & 15.20 \\
\hline Student-related and school-related variables & -45.67 & -37.30 & -44.88 & -53.33 & -29.33 & -16.34 \\
\hline Student-related and institutional variables & -36.80 & -29.48 & -35.74 & -43.34 & -23.02 & -13.78 \\
\hline School-related and institutional variables & -9.13 & -7.01 & -8.99 & -11.00 & -6.70 & -2.43 \\
\hline All variables & -45.67 & -37.30 & -44.88 & -53.33 & -29.33 & -16.34 \\
\hline Variables and constant & 7.69 & 12.15 & 7.44 & 3.90 & 8.83 & -1.14 \\
\hline
\end{tabular}

Source: Authors' calculations based on data from the Organisation for Economic Cooperation and Development (OECD), "PISA 2003" and "PISA 2006" [online] http://www.pisa.oecd.org/document/51/0,3746,en_32252351_32235731_39732595_1_1_1_1,00.html Note: Values expanded for the entire population.

ESCS: Index of Economic, Social and Cultural Status.

Effect of microsimulations on distribution indicators

\begin{tabular}{|c|c|c|c|c|c|c|c|c|c|}
\hline & \multicolumn{3}{|c|}{$\begin{array}{l}\text { Changes in only one } \\
\text { type of school }\end{array}$} & \multicolumn{3}{|c|}{$\begin{array}{l}\text { Changes in only one } \\
\text { type of school }\end{array}$} & \multicolumn{3}{|c|}{$\begin{array}{l}\text { Changes in only one } \\
\text { type of school }\end{array}$} \\
\hline & Gini $^{\mathrm{a}}$ & Public & Private & Theil $^{\mathrm{b}}$ & Public & Private & Entropy & Public & Private \\
\hline Total difference in PISA mathematics score & -0.004 & -0.003 & 0.001 & -0.001 & -0.001 & 0.000 & -0.002 & -0.001 & 0.000 \\
\hline Characteristics effect & -0.009 & -0.009 & 0.039 & -0.003 & -0.003 & 0.014 & -0.003 & -0.003 & 0.013 \\
\hline Weight effect & 0.003 & 0.004 & 0.039 & 0.001 & 0.002 & 0.013 & 0.001 & 0.002 & 0.013 \\
\hline Characteristics+weight effect & -0.001 & -0.001 & 0.039 & 0.000 & 0.000 & 0.014 & 0.000 & 0.000 & 0.013 \\
\hline Price effect & -0.007 & -0.005 & 0.038 & -0.003 & -0.002 & 0.013 & -0.003 & -0.002 & 0.013 \\
\hline Characteristics+weight+price effect & -0.010 & -0.009 & 0.039 & -0.004 & -0.003 & 0.013 & -0.003 & -0.003 & 0.013 \\
\hline Choice effect & 0.000 & 0.002 & 0.039 & 0.000 & 0.001 & 0.013 & 0.000 & 0.001 & 0.013 \\
\hline Characteristics + weight+price+choice effect & -0.005 & -0.005 & 0.040 & -0.002 & -0.002 & 0.014 & -0.002 & -0.002 & 0.013 \\
\hline Residual effect & -0.002 & 0.000 & 0.038 & -0.001 & 0.000 & 0.013 & -0.001 & 0.000 & 0.013 \\
\hline $\begin{array}{l}\text { Characteristics+weight+price+choice+ } \\
\text { residual effect }\end{array}$ & -0.008 & -0.007 & 0.039 & -0.003 & -0.002 & 0.013 & -0.003 & -0.002 & 0.013 \\
\hline
\end{tabular}

Source: Authors' calculations based on data from the Organisation for Economic Cooperation and Development (OECD), "PISA 2003" and "PISA 2006" [online] http://www.pisa.oecd.org/document/51/0,3746,en_32252351_32235731_39732595_1_1_1_1,00.html

Note: The entropy index was calculated using beta $=2$.

Choice effect: School selection effect.

a Gini coefficient.

b Theil index. 


\section{Bibliography}

Almeida dos Reis, J. and R. Paes de Barros (1991), "Wage inequality and the distribution of education: a study of the evolution of regional differences in inequality in metropolitan Brazil", Journal of Development Economics, vol. 36, No. 1, Amsterdam, Elsevier.

Amarante, V. and I. Perazzo (2008), "Crecimiento económico y pobreza en Uruguay. 1991-2006", Documento de trabajo, No. 09/08, Montevideo, Institute of Economics, University of the Republic.

Ammermüller, A. (2004), "PISA: what makes the difference? Explaining the gap in PISA test scores between Finland and Germany”, Discussion Paper, No. 04-04, Mannheim, Centre for European Economic Research.

ANEP (National Public Education Administration) (2007a), "Elementos para analizar la evolución reciente de la matrícula de educación secundaria", Montevideo.

(2007b), "Uruguay en PISA 2006. Primeros resultados en ciencias, matemática y lectura del Programa Internacional de Evaluación de Estudiantes", Montevideo.

(2004), "Primer informe nacional. PISA 2003 Uruguay", Montevideo.

Bellei, C. and others (2009), "Qué explica las diferencias de resultados PISA Lectura entre Chile y algunos países de la OCDE y América Latina”, ¿Qué nos dice pisa sobre la educación de los jóvenes en Chile? Nuevos análisis y perspectivas sobre los resultados en pisa 2006", Santiago, Chile, Ministry of Education, Unidad de Currículum y Evaluación.

Blinder, A. (1973), "Wage discrimination: reduced form and structural estimates", Journal of Human Resources, vol. 4, No. 8, Wisconsin, The University of Wisconsin Press.

Bourguignon, F., M. Fournier and M. Gurgand (1998), "Distribution, development, and education in Taiwan, 1979-94", Working Paper, Paris, DELTA.

Cardozo, S. (2008), "Políticas educativas, logros y desafíos del sector en Uruguay 1990 - 2008”, Cuadernos de la enia, No. 3, Montevideo, Comité de Coordinación Estratégica de Infancia y Adolescencia.

Fuchs, T. and L. Woessmann (2004), "What accounts for international differences in student performance? A re-examination using PISA data", iza Discussion Papers, No. 1287. Bonn, Institute for the Study of Labor.
Hanushek, E. and L. Woessmann (2010), "The economics of international differences in educational achievement", cesifo Working Paper, No. 3037, Munich, cEsifo.

Juhn, C., K. Murphy and B. Pierce (1993), "Wage inequality and the rise in return to skill", Journal of Political Economy, vol. 101, No. 3, Chicago, University of Chicago Press.

Llambí, C. and M. Perera (2008), "La función de producción educativa: el posible sesgo en la estimación de efectos "institucionales" con los datos PISA. El caso de las escuelas de tiempo completo", Montevideo, Economic Research Center (CINVE).

Méndez, N. and M. Zerpa (2009), "Desigualdad en las capacidades educativas en Uruguay y Chile", paper presented at the I Seminario sobre economía de la educación, Montevideo, Faculty of Economic Sciences and Administration, University of the Republic.

Oaxaca, R. (1973), "Male-female wage differentials in urban labor markets", International Economic Review, vol. 14, No. 3, Philadelphia, University of Pennsylvania/Osaka University Institute of Social and Economic Research Association.

OECD (Organization for Economic Cooperation and Development) (2006), pisa 2003: Manual de análisis de datos. Usuarios de spss ${ }^{\circledR}$, Madrid, Instituto Nacional de Evaluación y Calidad del Sistema Educativo (INECSE).

Pellegrino, A. and M. Koolhaas (2008), "Migración internacional: los hogares de los emigrantes", Demografía de una sociedad en transición: la población uruguaya a inicios del siglo XXI, C. Varela (coord.), Montevideo, Ediciones Trilce.

UNDP (United Nations Development Programme) (2008), Informe sobre desarrollo humano en Uruguay 2008. Política, políticas y desarrollo humano, Montevideo.

Valenzuela, J. and others (2009a), "Causas que explican el mejoramiento de los resultados obtenidos por los estudiantes chilenos en PISA 2006 respecto a PISA 2001. Aprendizajes y políticas", Santiago, Chile, Fondo de Investigación y Desarrollo en Educación, Ministry of Education.

(2009b), "Qué explica las diferencias de resultados PISA Matemática entre Chile y algunos países de la OCDE y América Latina”, ¿Qué nos dice pisa sobre la educación de los jóvenes en Chile? Nuevos análisis y perspectivas sobre los resultados en pisa 2006, Santiago, Chile, Ministry of Education, Unidad de Currículum y Evaluación. 